\title{
LAPAROSCOPIC MANAGEMENT OF CHOLECYSTOCOLIC FISTULA
}

\author{
Abordagem laparoscópica da fístula colecistocólica
}

Lauro Massaud CONDE, Pedro Monnerat TAVARES, Jorge Luiz Delduque QUINTES, Ronny Queiroz CHERMONT, Mario Castro Alvarez PEREZ

From Santa Casa de Bom Jardim, Bom Jardim, RJ, Brazil
ABSTRACT - Introduction: Cholecystocolic fistula is a rare complication of gallbladder disease. Its clinical presentation is variable and nonspecific, and the diagnosis is made, mostly, incidentally during intraoperative maneuver. Cholecystectomy with closure of the fistula is considered the treatment of choice for the condition, with an increasingly reproducible tendency to the use of laparoscopy. Aim: To describe the laparoscopic approach for cholecystocolic fistula and ratify its feasibility even with the unavailability of more specific instruments. Technique: After dissection of the communication and section of the gallbladder fundus, the fistula is externalized by an appropriate trocar and sutured manually. Colonic segment is reintroduced into the cavity and cholecystectomy is performed avoiding the conversion procedure to open surgery. Conclusion: Laparoscopy for resolution of cholecystocolic fistula isn't only feasible, but also offers a shorter stay at hospital and a milder postoperative period when compared to laparotomy.
HEADINGS - Biliary fistula. Intestinal fistula. Cholelithiasis/Complications. Cholecystectomy. Laparoscopy.
RESUMO - Introdução: A fístula colecistocólica é rara complicação das doenças calculosas do trato biliar. Sua apresentação clínica é variável e inespecífica, sendo o diagnóstico realizado, na maioria das vezes, incidentalmente durante o intraoperatório de sua causa base. A colecistectomia com fechamento da fístula é considerada o tratamento de escolha para a condição, sendo a videolaparoscopia cada vez mais reprodutível. Objetivo: Descrever a abordagem laparoscópica da fístula colecistocólica e ratificar a sua factibilidade mesmo diante da indisponibilidade de instrumentos mais específicos. Técnica: Após dissecção da comunicação e secção do polo vesicular, a fístula é exteriorizada por uma cânula adequada e rafiada manualmente. Reintroduzido o segmento colônico na cavidade, a colecistectomia é realizada evitando-se a conversão do procedimento para a operação aberta. Conclusão: A videolaparoscopia para resolução de fístula colecistocólica é viável, com menor tempo de internação hospitalar e melhor pós-operatório quando comparada à laparotomia.
DESCRTORES - Fístula biliar. Fístula
intestinal.
Colelitíase/complicações. Colecistectomia laparoscópica.

\section{INTRODUCTION}

T he bilioenteric fistulas, first described in 1890 by Courvoisier, are found in $0.15-8 \%$ of biliary tract operations. From them 8 to $26.5 \%$ are cholecistocolic and usually located at the hepatic flexure, with higher incidence in the elderly and in women ${ }^{1-4}$.

Chronic lithiasic diseases constitute the main cause, and though they occasionally are asymptomatic may present itself with variable clinical manifestations and diarrhea ${ }^{1,3.5}$. The diagnosis can be obtained by imaging and endoscopy; however, the difficulty in obtaining it lies in small clinical suspicion, since demonstrations are always somewhat inespecific, mainly diarrhea. In fact, the preoperative diagnosis is only made in only $7.9 \%$ of cases. When identified intraoperatively, the fistula should be addressed during surgery due to the risks of being malignant in origin or leading to complications $s^{3,6,7}$. In early intervention, complications occur in only $0.13 \%$ of cases. May manifest as acute cholecystitis, cholangitis, obstruction of the sigmoid colon by calculus impaction, gastrointestinal hemorrhages, hemobilia, local abscesses or even sepsis by contamination of the biliary tract by colonic bacteria ${ }^{3,8}$.

The rarity of this condition and the difficulties on its diagnosis justifies the small number of papers. In fact, nationwide the number is low, and even the foreign literature on the treatment for the condition, although been discussed for decades, surgical approach is still in doubt, regarding the best type of surgical access. 


\section{TECHNIC}

The surgical approach starts with usual general anesthesia with administration of antibiotic prophylaxis during induction. Through the umbilicus the pneumoperitoneum is done and are used the four portals as in the cholecystectomy. Chronic inflammatory process existing in the colon (usually transverse) adhered to the gallbladder is dissected using gauze, Maryland forceps and aspirator. Release the adhesions to confirm the existence of the fistula (Figure 1), then sectioning it from the gallbladder (Figure 2) and by a $11 \mathrm{~mm}$ trocar positioned on the right side (Figure 3), colonic segment is exteriorized and fistulous suture with two layers of Vicryl ${ }^{\circledR} 3.0$ is made. Repositioning the colon into the abdominal cavity and dissection of biliary pedicle is performed. To facilitate the mobilization of the gallbladder, the infundibulum is opened to remove the stone(s). Dissection of the cystic duct and cystic artery is also made with blunt maneuvers, performed whenever possible without the use of electrocautery. After cholecystectomy, positioning a Penrose drain on the gallbladder bed and over the colon suture (Figure 4) is done, removed on hospital discharge (Figure 5).

This procedure was performed in one patient, uneventfully, keeping antibiotics for two days. Oral diet was introduced on the second day and discharged on the fifth. The evolution was clinically without any complications postoperatively. Colonoscopy scan performed after six months showed complete closure of the fistula.
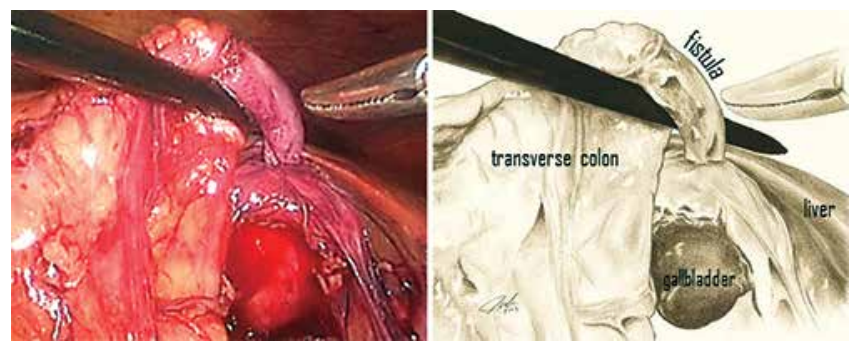

FIGURE 1 - Dissection of the fistula between the transverse colon and fundus of the gallbladder

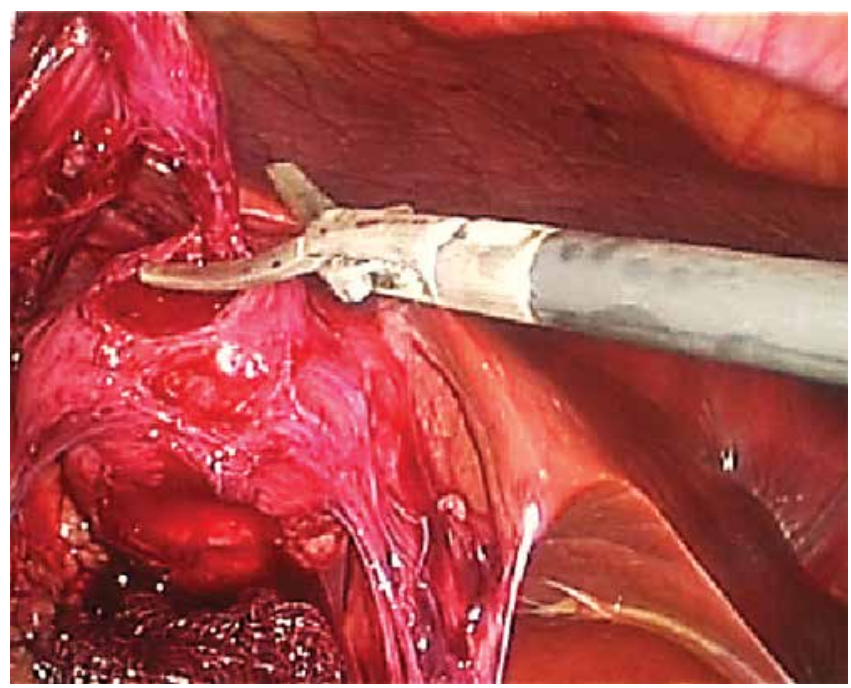

FIGURE 2 - Fistula being separated from the gallbladder

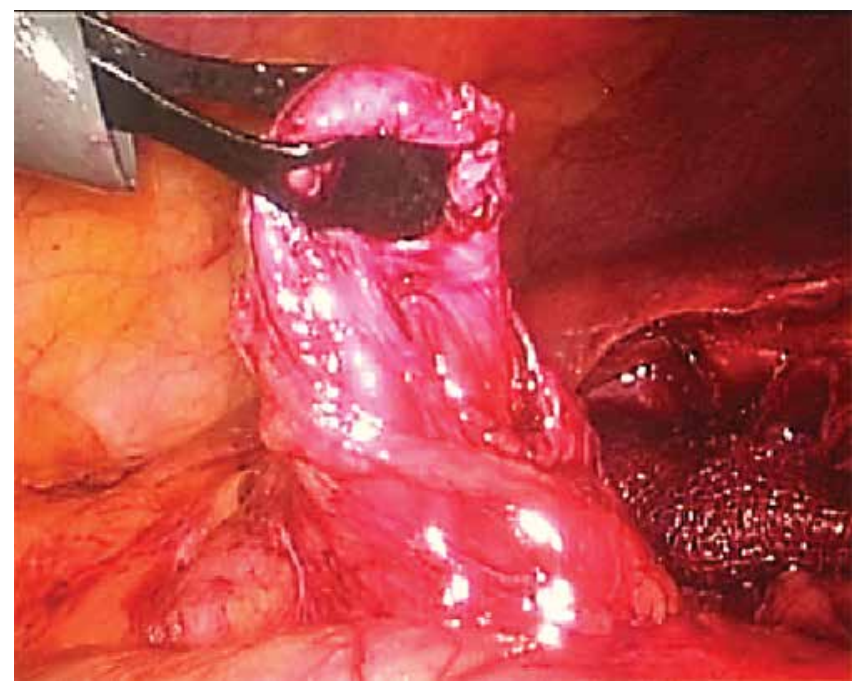

1 - Fistula and colon segment being removed through the trocar of $11 \mathrm{~mm}$

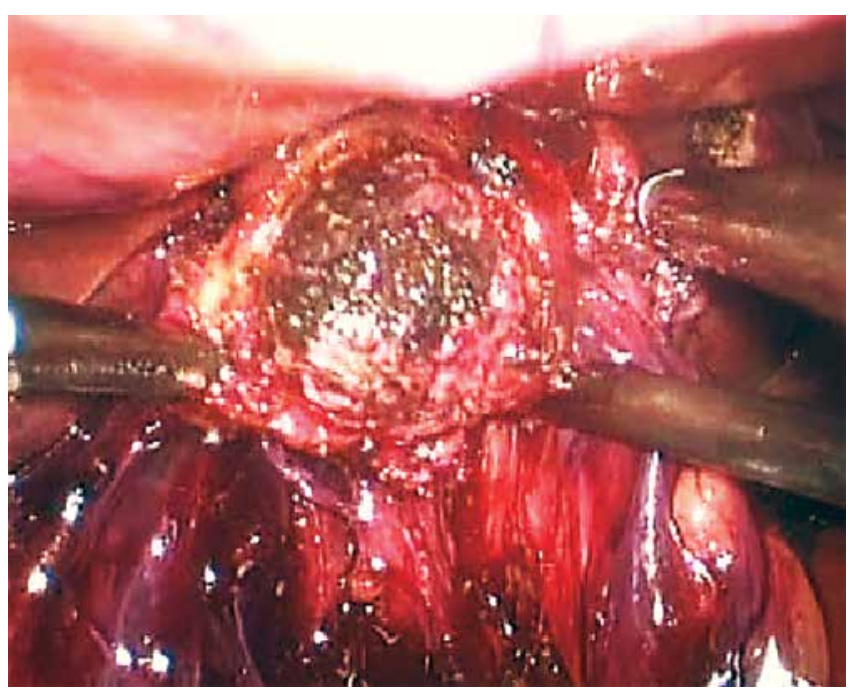

FIGURA 4 - Cálculo sendo extraído pelo fundo da vesícula.

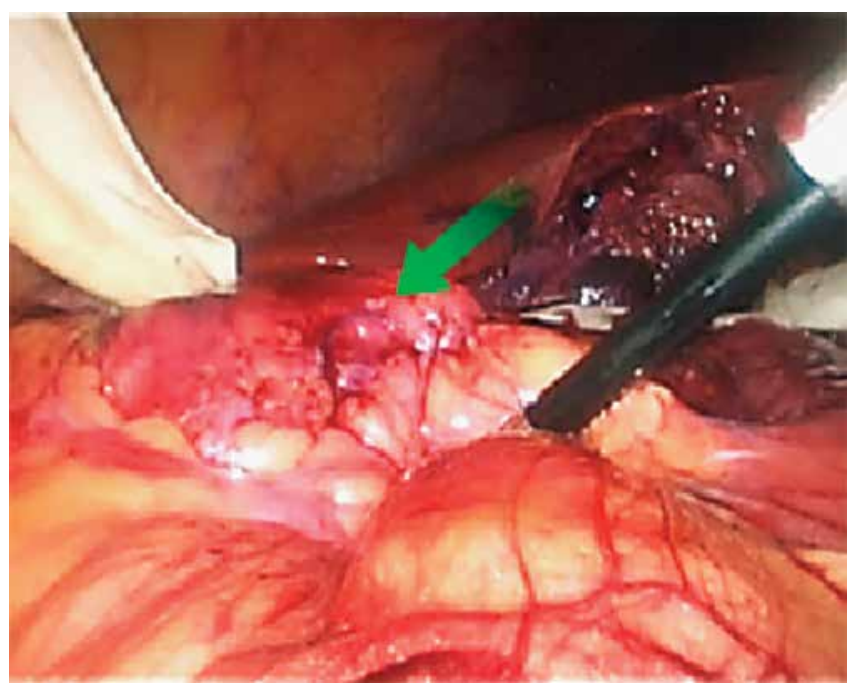

FIGURE 5 - Positioning the Penrose drain; the arrow indicates the fistuloraffia on the colonic segment 


\section{DISCUSSION}

Given to the technical evolution in laparoscopy, the progressive learning curve has led surgeons continually to proficiency in higher levels, and prior situations that would be indicative of laparotomy, now become increasingly amenable in laparoscopic treatment; the treatment of fistulas have also this tendency, not being contraindicated any more to laparoscopy ${ }^{3,4,6}$.

Interestingly, the main cause of conversion to laparotomy in laparoscopic cholecystectomy is the intense tissue inflammation ${ }^{9,2}$.

Even being new approach in Brazil the resolution of digestive fistula by laparoscopy has been cited in numerous publications abroad ${ }^{2-4,6,10,11}$. Nevertheless, there are still authors who, even today, consider laparotomic cholecystectomy the procedure of choice to treat cholecystocolic fistula ${ }^{7}$. CHOWBEY et $\mathrm{al}^{2}$ showed a large number of cases of fistulas approached laparoscopically at a conversion rate of only $6.3 \%$. Therefore, subject to the availability of resources, and favorable risk-benefit ratio of the procedure, this experiment confirms the laparoscopic approach to fistulas. In addition to technical difficulties, the risks of iatrogenic complications is inherent to all operations, and can also influence the choice of surgical approach. However, the resolution of biliary fistulas have no differences between laparoscopy and laparotomy approaches, based on intra and postoperative complications ${ }^{4}$. Therefore, most current discussion should not stick to how to approach cholecystocolic fistula by laparoscopy, but when you convert it.

The fistula dissection and suture of the colon must be performed before starting the cholecistectomy ${ }^{10,12}$. In most studies, the choice of procedures is not discussed, nor justified by the authors. However, it is believed that the possibility of contamination of the cavity by colonic bacteria can be minimized with it.

The use of electrocautery should be avoided due to the possibility of delayed thermal injury and, therefore, should be used blunt dissection of the fistula and biliary tree ${ }^{2}$. Although the fistula is closed by manual suturing, the most practical technique, according to recent literature, is the use laparoscopic staplers ${ }^{2}$. In fact, manual suture, either intra or extracorporeal, is only technically more difficult prolonging surgical time. Fujitani et al. ${ }^{11}$, for example, in describing the first suture of manual cholecystocolonic fistula, took 202 minutes to complete the operation. The operation reported here finished in $115 \mathrm{~m}$. The fistulotomy and colon raffia took about $1 \mathrm{~min}$ to be performed, while the whole process plus the time to remove the colon and return it to the cavity ended up taking about $6 \mathrm{~min}$. Therefore, given the short time required for the extracorporeal manual closure of the fistula, it is believed that the unavailability of staplers or the inexperience of the surgeon regarding laparoscopic suturing, are not justifications for laparotomy conversion. Another alternative on the unavailability of staplers would be to use endoloop ${ }^{4,6}$.

Analogous to simple cholecystectomy, in general, one can say that the longer surgical time of laparoscopy for resolution of the fistula when compared to laparotomy, proves to be irrelevant in face of small inflammatory response associated with laparoscopic surgical trauma. What can illustrate this is the lowest average hospital stay of patients operated by laparoscopy compared to laparotomy (3vs17 days) ${ }^{4}$.

One should not leave gallbladder or colonic fistula tissue in the operative field. This care is important to allow to find malignancy in histopathological examination, and prevents gallbladder tissue, not removed, eventually become ischemic leading to complications $\mathrm{s}^{6,12}$.

Regarding the use of the Penrose drain, although the decision to use it and the choice of length of stay are intuitive to the surgeon himself, its believed to be prudent to leave it on operative field. CHOWBEY et $\mathrm{al}^{2}$, for example, operating 73 cases to treat fistulas associated with cholecystectomy, drainage system was used in all cases.

Thus, the fact that this is the first reported case of cholecystocolonic fistula approached laparoscopically in Brazil ends up encouraging discussion on the subject in our country.

\section{CONCLUSION}

The procedure is feasible. However, the choice of the type of access and the strategy to be employed should be individualized based on diagnosis, patient characteristics, availability of resources, the experience and judgment of the surgeon.

\section{REFERENCES}

1. Balent E, Plackett TP, Lin-Hurtubise K. Cholecystocolonic Fistula. Hawaii J Med Public Health. 2012; 71(6):155-7

2. Chowbey PK, Bandyopadhyay SK, Khullar R, Baijal M. Laparoscopic Management of Cholecystoenteric Fistulas. J Laparoendosc Adv Surg Tech. 2006; 16(5):467-72.

3. Costi R, Randone B, Violi V, Scatton O, Sarli L, Soubrane O, Dousset B, Montariol T. Cholecystocolonic fistula: facts and myths. A review of the 231 published cases. J Hepatobiliary Pancreat Surg. 2009; $16: 8-18$

4. Angrisani L, Corcione F, Tartaglia A, Tricarico A, Rendano F, Vincenti $\mathrm{R}$, Lorenzo M, Aiello A, Bardi U, Bruni D, Candela S, Caracciolo F, Crafa F, De Falco A, De Werra C, D'Errico R, Giardiello C, Petrillo O, Rispoli G. Cholecystoenteric fistula (CF) is not a contraindication for laparoscopic surgery. Surg Endosc. 2001; 15:1038-41.

5. Bernardo FCS, Junior FO, Almeida MG, Volpiani JÁ, Jacinto JAM, Baraviera AC, Kiss DR. Fístula Colecistocólica - Relato de Caso. Rev Bras Colo-Proct. 1997; 17(3):191-3.

6. Wang WK, Yeh CN, Jan YY. Successful laparoscopic management for cholecystoenteric fistula. World J Gastroenterol. 2006; 12(5):772-5.

7. Antonacci N, Taffurelli G, Casadei R, Ricci C, Monari F, Minni F. Asymptomatic Cholecystocolonic Fistula: A Diagnostic and Therapeutic Dilemma. Case Rep Surg. 2013 (doi:10.1155/754354). Disponível em http://dx.doi.org/10.1155/2013/754354.

8. Jorge JX, Sousa LA, Panão EA, Campos MJ, Gonçalves A, Vale AC, Pontes FA. Fístulas biliodigestivas litiásicas (a propósito de 3 casos clínicos). GE J Port Gastrenterol. 2013; 20(3):119-22.

9. Genc V, Sulaimanov M, Cipe G, Basceken SI, Erverdi N, Gurel M, Aras $\mathrm{N}$, Hazinedaroglu SM. What necessitates the conversion to open cholecystectomy? A retrospective analysis of 5164 consecutive laparoscopic operations. Clinics. 2011; 66(3):417-20.

10. Ibrahim IM, Wolodiger F, Saber AA, Dennery B. Treatment of cholecystocolic fistula by laparoscopy. Surg Endosc. 1995; 9:728-9.

11. Fujitani K, Hasuike Y, Tsujinaka T, Mishima H, Takeda Y, Shin E, Sawamura T, Nishisyo I, Kikkawa N. New Technique of LaparoscopicAssisted Excision of a Cholecystocolic Fistula: Report of a Case. Surg Today. 2001: 31:740-2.

12. Prasad A, Foley RJE. Laparoscopic management of cholecystocolic fistula. Br J Surg. 1994; 81:1789-90. 